\title{
Changing Import Preferences and Their Impact on The Effects of Trade Liberalization
}

\author{
TZU-HANYANG*, HAN-PANGSU**
}

\begin{abstract}
In the last two decades, the dependence of Taiwan's manufacturing production on imported intermediate inputs has steadily risen. Meanwhile, the market share of imported consumable manufacture products has also increased. The steady rise of both import shares may not be explained by price fact or since the relative import prices have shown no decreasing trend. The scenario of constantly buying more imported goods when they are not cheaper can be treated as a preference change in favor of imported goods, which may be caused by the popularity of outsourcing, increasing product varieties and persistent trade barriers, as literatures indicated. Traditional macroeconomic models primarily consider the price mechanism in their import demand estimates, with no concern for changes in import preferences. Neglecting changing import preferences in a rapid globalization environment may yield biased empirical results. In this article, we incorporate the import preference factor into a single-country Computable General Equilibrium (CGE) model and use it firstly to quantify the scale of preferences change and then to test how the preferences change affects the effects of trade policy. The empirical results with and without the concern of import preferences change are compared to yield the scale of bias caused by neglecting the change.
\end{abstract}

Key Word: import preference, trade liberalization, Armington assumption, CGE model

JEL classification: F12,F13, F14

\footnotetext{
* Professor, Department of Public Finance, National Taipei University, New Taipei City, Taiwan, R.O.C.

** Chief, Research Division III, Taiwan Research Institute, New Taiwan City, Taiwan, R.O.C.

Corresponding author, email address: hpsu@tri.org.tw
} 


\section{Introduction}

In the last two decades, the dependence of Taiwan's manufacturing production on the imported intermediate inputs has shown arising trend. As shown in Table 1, the intermediate inputs purchased from abroad for Taiwan's manufacturing production had increased disproportionally. The share of its value to the total manufacturing output grew from $35.5 \%$ in 1996 to $39.5 \%$ in 2011. Meanwhile, the market share of imported consumable manufacture products also increased. The market share of imported consumable manufacture goods had steadily grown from $29.4 \%$ in 1996 to $41.2 \%$ in 2011 .

\section{Table 1.}

The share of imported intermediate inputs on Taiwan's manufacturing production and the market share of imported consumable manufactures in Taiwan

\begin{tabular}{c|c|c|c|c}
\hline & $\mathbf{1 9 9 6}$ & $\mathbf{2 0 0 1}$ & $\mathbf{2 0 0 6}$ & $\mathbf{2 0 1 1}$ \\
\hline $\begin{array}{c}\text { Value share of imported intermediate } \\
\text { inputs on manufacturing production }\end{array}$ & 35.5 & 37.5 & 40.9 & 39.5 \\
\hline $\begin{array}{c}\text { Market share of imported } \\
\text { consumable manufacture goods } \\
\text { (measured by sales value) }\end{array}$ & 29.4 & 32.8 & 37.0 & 41.2 \\
\hline
\end{tabular}

Source: Directorate-General of Budget, Accounting and Statistics, Executive Yuan, R.O.C.(Taiwan), Input-Output Tables, various years.

The constant increase in import shares indicated the substitution of domestic goods by the imported goods. We may expect the relative import prices to decline so that the imported goods became more competitive. However, it is not the case. In the last twenty years, the relative prices of imports have not exhibited a decreasing trend. The scenario suggests that the increasing demand for imports may not be drawn largely by price consideration. Non-price factors may also play an important role. In this article, we treat the scenario of constantly buying more imported goods when they are not cheaper as a preference change in favor of imported goods, which may be caused by the reinforcement of global outsourcing, increasing product varieties and persistent trade barriers, as literatures indicated. We establish a single-country CGE model and apply it to Taiwan data first to quantify the import preference change and then to estimate how the preference change affects the import demand, and consequently alters the effects of trade liberalization policy on its macroeconomic performance. By comparing the empirical results with and without the concern of preference change, we present the bias caused by neglecting the 
change.

In many empirical studies of trade issues, the Armington assumption (Armington 1969,1970 ) is made to describe the behavior of import demand. It states that a product (for example, semiconductor) produced by firms of different countries (say, Japan and China) are differentiated and substitutable with each other. The feature of product differentiation make it reasonable for a firm to buy from different sources (i.e., domestic or imports from different countries) simultaneously; and the feature of substitutability motivate a firm to adjust its purchase allocation responding to the relative price change. Indeed, this approach has the advantage of precisely capturing the demand effect due to relative (domestic/ import) price changes in a monopolistic competitive market.

On the other hand, the import demand effect from factors other than price has attracted much attention of empirical researchers in the recent years. Buetre and Ahmadi-Esfahani (2000) found that producers may have to purchase parts and components from a particular country or of a specific brand in response to the requests of their customers, in particular the ones with long-term contracts. Rigoberto (2005) noted that trade protections may affect the purchase allocation between domestic and imported inputs. Feenstra (1994a) discovered that an increase in availability of more finely differentiated imported products will stimulate more import demand. Failure to recognize this "variety effect" may result in a biased estimation of the substitution effect caused by relative price changes. These findings provide various reasons for how the import preference may change. Neglecting the changing import preferences in a rapid globalization environment with the popularity of outsourcing, the availability finely differentiated products, and the persistent trade barriers may yield biased empirical results.

Taiwan is a small and highly open economy; it is home to many suppliers of intermediate products and contract producers in the global production chain. Firms in Taiwan very commonly provide production services for brand owners through original equipment manufacturing (OEM) or original design manufacturing (ODM). When a firm is responsible for only a part of a production process that is managed by a brand owner, the choice of input sources is generally not based on price but constrained by the requirements of the brand owners. However, domestic firms that produce final goods (such as automobiles) for the domestic market may also be constrained in their purchase of key components by the foreign suppliers with which they have technological alliances. For these reasons, firms may make their input purchases that are not based only on price, but also on other non-price factors. The change in import demand that is caused by the aforementioned factors is referred herein as the "preference effect".

To quantify the scale of preference change and analyze its effect, this paper modifies the method of Horridge (2004), who incorporated a preference factor into various demand 
functions of a CGE model. We follow his design of incorporating a preference factor into the import demand equations of our model; carefully decompose the terms of equation to endow the meaning; and use it to do the empirical work of measuring the preference change of Taiwan between 1999 and 20041), in which period the trade liberalization policies were executed for its entry into WTO in 2002. Estimation is also conducted to see how the import preference change affects the economic effects of the policies. A comparison of the results with and without the preference change may help to reveal the bias that arises from neglecting the preference effect.

The rest of the paper is organized as follows. The next section reviews the relevant literature. The third section introduces the methodology, including the derivation of the import demand equations and the steps of simulation, and data structure. The fourth section first describes the relevant data used for empirical study and then presents and interprets the empirical results. The fifth section draws conclusions.

\section{Literature Review}

\subsection{Production globalization and change in import demand}

After the end of the Cold War and the collapse of the USSR, the world trade had entered into a new stage and the global trade experienced an extraordinary growth. The scenario has drawn much attention from economists and new trade theories had flourished to interpret it. Some focus on product differentiation and note that the disproportionate expansion of import demand is partly caused by an increase in the available varieties of products. By developing the theory of how product variety can affect firms' or industries' productivity and establishing an empirical method to quantify the time trend of U.S. manufacturing product varieties, Feenstra (1994a) found that neglecting the change of product variety may generate results in overestimates of income elasticity and incorrect substitution elasticity of import demand. Feenstra and Markusen (1994b) further explained that if imported products are heterogeneous intermediate inputs or capital goods, then the openness of trade may provide more choices that better meet the various needs of domestic producers that operate on different scales and use different production technologies. In such a case, an increase in the range of available varieties can reduce domestic production costs, improve production efficiency, and therefore simultaneously increase import demand and

1) This sample period is chosen owing to the availability of the input-output data for the years 1999 and 2004. 
domestic production. However, if the imported goods are consumable goods, then an increase in variety may increase domestic consumption, while the demand for domestic products may be partially replaced by demand for imported products. Therefore, the overall effect of importing differentiated products on domestic production is uncertain. Moreover, an increase in product variety may affect price elasticity. Feenstra and Taylor (2008) asserted that purchasers will become more price-sensitive when they have more varieties to choose.

Other economists emphasize the fragmentation and outsourcing of production. Feenstra and Taylor (2008) and Robertson (2004) both noted that the global trend toward production outsourcing not only accelerates trade in intermediate goods, but also causes the geographical concentration of specific production activities. Greater production fragmentation not only widens the wage gap between skilled and unskilled workers, but also increases the frequency of flows of goods and components across borders, as reflected by the extraordinary growth of imports and exports. Gereffi and Fernandez-Stark (2011) further discussed how the development of global value chains provided a stepping stone for developing countries to integrate into the global economy, consequently making their imports and exports to increase. Wang et al. (2013) and Koopman et al. (2014) carefully described the evolution of the pattern of global production fragmentation and outsourcing and how the pattern evolution has changed the implications of global trade statistics.

In their study of the rapidly increasing flow of U.S. food imports during 2002-2007, Brooks et al. (2009) found that it was contributed by two key factors, namely, improved market accessibility and evolving consumer demand. For the former, the advancement in transportation and marketing logistics, together with the expansion of multinational companies, has enabled local grocery stores to offer a wide array of foods for sale. For the latter, as Americans become better educated, wealthier and more ethnically diverse, their demand for diverse, convenient and healthful food also increased (Frazao et al. 2008). We may interpret such import increase as induced by the change of objective environment (improved market accessibility) and the change of consumers' subjective inclination. Both may draw to a change of preference in favor of imports.

The aforementioned studies all indicate the importance of the effect of non-price factors, or in our term, preference effect, and provide some evidence of the bias that may be caused by neglecting this effect. However, the magnitude of preference change has not been explicitly measured and its effect has not been properly evaluated. The following section establishes a quantitative model firstly to measure the preference change, and then to evaluate the effects of the change on economic performance. 


\subsection{Import demand function and Armington assumption}

In empirical studies of trade policies, the Armington(1969, 1970) assumption is typically used to describe the substitutive relationship between imports and domestic products. The Armington assumption treats same products that are imported from different countries or regions as differentiated but substitutive. The demand for imports is derived from the optimal behavior of producers that minimizes their costs and that of consumers that maximizes their utility. This approach not only properly considers the price mechanism but also reflects the feature of product differentiation in a monopolistic competitive market. In addition, it can accommodate the phenomenon that a country produces and exports a product and simultaneously imports the same product from various countries, as most countries do. Since it can properly describe the trade practices in the real world, it is adopted by most trade models, such as that of Alston et al. (1990) to analyze American trade in cotton and wheat and that of Küster et al.(2007) to evaluate the effects of energy policy on the labor market, to name only a few.

In the CGE model practice, the Armington assumption is usually incorporated with CES (constant elasticity of substitution) import demand function with fixed substitution elasticity parameters. This setting is appropriate for static comparative policy analysis or short-run analysis when domestic and international production network structure remain stable. However, for a small, open economy that faces rapidly deepening global production fragmentation, failure to consider preference changes may yield biased results.

\section{Methodology}

In this section, we first introduce the method of CGE modeling, and then explain how the mechanism of preference change is incorporated into our CGE model by modifying the input demand equations. Thirdly, three types of simulations are presented to illustrate the calibration of preference change (historical simulation), the identification of the effects of preference change (decomposition simulation), and how the preference change affects the macroeconomic effects of trade liberalization policy (policy simulation). At the last section, we introduce the data structure used by our CGE model.

\subsection{CGE modeling}

The method we adopt to carry out the empirical study is CGE modeling. General 
speaking, there are two prototypes of CGE model, one is the DMR-type model, originally established by Dervis et al. (1982) for the World Bank to conduct a series of studies of the development issues in the developing countries. The DMR-type model comprises a set of equations that describe not only the flows of goods and factors within and among production sectors but also the flows of income and expenditure between household and production sectors. The equilibrium solution is obtained by simultaneously solving the original nonlinear equations using the scheme of linear programming. Owing to the complexity and difficulty of solving a large set of nonlinear equations, the expansion of model to incorporate more disaggregate economic activities is somewhat constrained. In recent years, the ORANI-type model, originally developed by the Center of Policy Studies, Monash University, Australia, has been widely used in trade policy research.2) The ORANI-type model does not require the formulation of a social accounting matrix (SAM), as it uses only data from input-output tables, which considerably reduces the workload of researchers. With lower requirement of data, it focuses on the analysis of resource allocation efficiency and is less concerned with flows of income and expenditure. In addition, its simulation solution is carried out using linear transformation scheme developed by Johansen (1960), which transforms the original nonlinear equations into linear equations by using natural logarithm and first-order differentiation. With the help of multi-step extrapolation, the solution can be easily generated without much loss of accuracy. This process greatly simplifies the solution method and makes feasible the development and solving of a large and more detailed model.

The CGE model used here is adapted from Yang and $\mathrm{Su}$ (2002) based on the structure of the ORANI model, which comprises three parts of equations that describe the input-output relations among industries, the optimal behaviors of producers and consumers, and market equilibrium conditions. To supplement the lack of links between income and final demand in the ORANI model, we add the income-expenditure equations referring to the DMR model so that the model is complete with both production and income aspects of an economy.

In this model, we use nested CES inputs demand functions to describe the decision-making of domestic firms in purchase allocation between domestic and import inputs. The CET (constant elasticity of transformation) output functions are used to describe domestic firms'decision in allocating their output between domestic sales and exports. The primary inputs for production are labor, capital and land, which are governed by a CES function that reflects the choices made by firms seeking to minimize costs under technological constraints. The linear expenditure system is utilized to describe how

2) See Dixion et al.(1982) for model details 
consumers spend their expenditures among various goods. Appendix presents the main structure and key equations of the model.

\subsection{The mechanism of preference change}

The import demand function with the feature of Armington assumption can capture changes in import demand responding to changes in relative import prices, but it does not capture changes in import demand that are caused by non-price, preference factors. To include preference effect into our analysis, a preference change mechanism has to be incorporated into input demand equation, which is described as follows.

For producer $j$, let $X_{i}$ ( $i=d$ : domestic goods, $m$ : import goods) be the quantity of inputs. The demands for domestic input $X_{d}$ and imported input $X_{m}$ are governed by a CES function to minimize production costs within technological constraints. $Z$ represents a given effective amount of inputs which can be generated by various combinations of $X_{d}$ and $X_{m}$. The optimal behavior of producer $j$ can be expressed as,

$\operatorname{Min} \sum_{i} P_{i} X_{i}$, subject to $Z=\left(\sum_{i} \delta_{i} X_{i}^{-\rho}\right)^{-1 / \rho}$

By using Lagrange formula, the first-order condition is derived as,

$P_{k}=\Lambda \frac{\partial Z}{\partial X_{k}}=\Lambda \delta_{k} X_{k}^{-(1+\rho)}\left(\sum_{i} \delta_{i} X_{i}^{-\rho}\right)^{-(1+\rho) / \rho}, j, k=d, m j \neq k$

Accordingly, the relative price can be expressed as,

$$
\begin{aligned}
& \frac{P_{k}}{P_{i}}=\frac{\delta_{k}}{\delta_{i}}\left(\frac{X_{1}}{X_{k}}\right)^{1+\rho} \\
& \text { or } X_{i}^{-\rho}=\left(\frac{\delta_{i} P_{k}}{\delta_{k} P_{i}}\right)^{-\rho /(\rho+1)} X_{k}^{-\rho}
\end{aligned}
$$

Substituting Eq. (4) back to the CES function in (1) yields, 
$Z=X_{k}\left(\sum_{i} \delta_{i}\left[\frac{\delta_{k} P_{i}}{\delta_{i} P_{k}}\right]^{\rho /(\rho+1)}\right)^{-1 / \rho}$

Therefore the factor demand function is,

$$
\begin{aligned}
& X_{k}=Z\left(\sum_{i} \delta_{i}\left[\frac{\delta_{k} P_{i}}{\delta_{i} P_{k}}\right]^{\rho /(\rho+1)}\right)^{1 / \rho} \\
& \text { or } X_{k}=Z \delta_{k}^{1 /(\rho+1)}\left[\frac{P_{k}}{P_{\text {ave }}}\right]^{-1 /(\rho+1)}
\end{aligned}
$$

where $P_{\text {ave }}=\left(\sum_{i} \delta_{i}^{1 /(\rho+1)} P_{i}^{\rho /(\rho+1)}\right)^{(\rho+1) / \rho}$

Equation (7) describes the standard price mechanism that is used to determine the input combination of domestic and imported goods. $P_{\text {ave }}$ denotes the price of the composite input $Z$. Using lowercase to represent percentage changes in the variables of Eqs. (7) and (8), we obtain the transformed linear equations (9) and (10).

$$
\begin{aligned}
& x_{k}=z-\sigma\left(p_{k}-p_{\text {ave }}\right) \\
& p_{\text {ave }}=\sum_{i} S_{i} p_{i}
\end{aligned}
$$

where $\sigma=\frac{1}{\rho+1}, S_{i}=\delta_{i}^{1 /(\rho+1)} P_{i}^{\rho /(\rho+1)} / \sum_{k} \delta_{k}^{1 /(\rho+1)} P_{k}^{\rho /(\rho+1)}$

Now we replace Eqs. (9) and (10) with Eqs. (11) and (12) below, in which the term of preference changes $\left(a_{i}\right)$ is added into the model:

$$
\begin{aligned}
& x_{i}-a_{i}=z-\sigma\left(p_{i}+a_{i} \widetilde{P}_{a v e}\right) \\
& \widetilde{P}_{a v e}=\sum_{i} S_{i}\left(P_{i}+a_{i}\right)
\end{aligned}
$$

The term $a_{i}$ appears twice in Eq. (11); $a_{i}<0, i=m$, represents the increase in the relative preference for imports because each unit of imported inputs provides more production services (or higher efficacy in production) than a unit of domestic input so fewer 
physical imported units are required to generate the same amount of output, as specified by the left-hand side of Eq. (11). For example, meeting the request of a contract partner to use imported parts and components of a specified brand facilitates production. On the other hand, A lower price of each effective unit of imports $\left(p_{i}+a_{i}\right), i=m$ leads to the substitution of domestic products for imports even when the price of a physical unit of imports $\left(p_{i}\right)$ remains the same, as specified by the right-hand side of Eq. (11).

As specified by Eq. (12), when $a_{i}<0, i=m$, the price of the composite input Pave is reduced, meaning that replacing domestic inputs with imports will lower the price of an effective unit of composite inputs. This price change leads to adjustment of the input combination in favor of imports. The adjustment in the input combination results in a larger share of the input cost for imports. The task here is to decompose the effects of price changes and preference changes on the expansion of the input cost share for imports.

Refering to Buetre and Ahmadi-Esfahani (2000) and Horridge (2004), Eqs.(11) and (12) are further extended as follows.

$$
\begin{aligned}
& \begin{array}{r}
x_{d}-a_{i}=z-\sigma\left(p_{d}+a_{d} S_{d}\left(p_{d}+a_{d}\right)-S_{m}\left(p_{m}+a_{m}\right)\right) \\
=z-\sigma S_{m}\left(\left(p_{d}+a_{d}\right)-\left(p_{m}+a_{m}\right)\right)
\end{array} \\
& \text { and } x_{m}-a_{m}=z-\sigma\left(p_{m}+a_{m}-S_{d}\left(p_{d}+a_{d}\right)-S_{m}\left(p_{m}+a_{m}\right)\right) \\
& \qquad=z-\sigma S_{d}\left(\left(p_{d}+a_{d}\right)-\left(p_{m}+a_{m}\right)\right) \\
& \text { where } \tilde{p}_{\text {ave }}=\sum_{i} S_{i}\left(p_{i}+a_{i}\right)=R_{d}\left(p_{m}+a_{m}\right)-R_{m}\left(p_{d}+a_{d}\right)
\end{aligned}
$$

Let $t=\left(x_{d}-x_{m}\right)$ be a twist variable, representing the rate of relative change of domestic and imported inputs, given that $p_{d}=p_{m}=\tilde{p}_{\text {ave }}=0$.

$$
S_{d} a_{d}+S_{m} a_{m}=0,
$$

and $x_{d}-x_{m}=(1-\sigma)\left(a_{d}-a_{m}\right)=t$

Now, $a_{d}$ and $a_{m}$ can be expressed as

$a_{d}=S_{m} t /(1-\sigma)$ and $a_{m}=S_{d} t /(1-\sigma)$ 
Substituting Eq. (18) back into the demand functions for domestic goods (13) and imported goods (14), yields,

$$
x_{d}=z+S_{m} t /(1-\sigma)-\sigma S_{m}\left(\left(p_{d}-p_{m}+S_{m} t /((1-\sigma))+S_{d} t /(1-\sigma)\right)\right)
$$

and $x_{m}=z-S_{d} t /(1-\sigma)-\sigma S_{d}\left(\left(p_{d}-p_{m}+S_{m} t /((1-\sigma))+S_{d} t /(1-\sigma)\right)\right)$

which can be further simplified as,

$$
\begin{aligned}
& x_{d}=z+S_{m} t-\sigma S_{m}\left(p_{d}-p_{m}\right) \\
& x_{m}=z+S_{d} t-\sigma S_{d}\left(p_{d}-p_{m}\right)
\end{aligned}
$$

The three components on the right-hand side of Eqs. (21) and (22) can be interpreted as follows.

(1) $z$ : the ouput effect,

(2) $\sigma S_{k}\left(p_{d}-p_{m}\right)$ : the price effect based on the Armington assumption $(k=d, m)$, and

(3) $S_{k} t$ : the preference effect.

Note that the second and third terms on the right-hand side of Eq. (21) have the opposite signs with those of Eq. (22). When $t>0$, it signifies that consumers become more in favor of domestic goods. Given relative prices, they intend to purchase more domestic goods and fewer imported goods; when $t<0$, consumers become more in favor of imported goods. Given relative prices, they intend to purchase fewer domestic goods and more imported goods.

\subsection{The methods of simulation}

Three types of simulation are implemented in sequence for the purposes of (1) calibrating the change of preference (historical simulation), (2) decomposing the macroeconomic changes to the contribution of preference change (decomposition simulation), and (3) simulating the economic impacts of the trade liberalization policy with preference change (policy simulation). The results of the policy simulation are compared with the simulation results without the concern of the preference change so that the bias of 
the latter can be revealed. ${ }^{3)}$ All three simulations are using the same model framework. By specifying different closures, we are able to generate the results for the different purposes above. 4)

\section{A. Historical simulation}

Historical simulation specifies its closure to include the variables that are readily observed from statistical sources in the exogenous set. It consists of (domestic and imported) intermediate input flows of commodity $i$ to industry $j$, which data are available from input-output tables, and macroeconomic variables such as household consumption, government expenditure, import and export price indexes, which data are available from the national income statistics. By plugging the values of these exogenous variables in the model, we are able to calibrate the change of unobservable variables, such as productivity changes and preference changes. This process is called historical simulation. We adopt this process in our modified CGE model accommodated with the factor of preference change. The results are shown in section 5 .

\section{B. Decomposition simulation}

In a decomposition simulation, we include in the exogenous set the variables not naturally explained in a CGE model. These variables may be observable such as government expenditure and tax rates, or unobservable such as productivity changes and preference changes.

In our empirical study, we plug the value of the calibrated preference changes in the model as exogenous shocks so that we can estimate their impacts on variables of interest. Through this process, the economic effects caused by the preference changes can be identified.

3) For the details of the three simulation methods, please refer to Dixon and Rimmer (2000).

4) The closure of a CGE model is the classification of endogenous and exogenous variables. Mathematically, the basic requirement to obtain a unique solution of a simultaneous equation system is that the number of equations equals the number of endogenous variables. In a CGE model, the number of variables is usually greater than the number of equations. Therefore some of the variables must be treated as exogenous. By classifying different sets of endogenous and exogenous variables, a CGE model can be utilized for different purposes. 


\section{Policy simulation}

In the policy simulation, the exogenous set of variables includes the policy variables and unobservable variables such as preference changes and productivity changes that are obtained in historical simulation. By shocking the policy variables, we simulate the economic impacts of the tariff reduction Taiwan had pledged to take for the entry into WTO. The empirical results with and without the consideration of the import preference changes are compared so that the bias of the latter can be revealed.

\subsection{Data structure}

The data used in our empirical study can be divided into the following two sets.

(1) Data related to input-output production relations are taken from the Input-Output Tables, which were published by the Directorate-General of Budget, Accounting and Statistics (DGBAS), Executive Yuan, R.O.C. It provides the abundant information about interactive relationships among industries and between household and production sectors.

(2) Data related to income and expenditure are taken from the National Income Accounts and the Survey of Family Income and Expenditure, also published by the DGBAS. This set of data are mainly macroeconomic variables

To generate the flows and links between production and household sectors, industrial payments for primary inputs, intermediate inputs and indirect taxes are connected to the revenues of the households, businesses and government respectively. After deducting household direct tax and adding government direct transfer, household income is obtained, based on which households make their consumption spending on various goods. Figure 1 presents the economic flows and interactions that are related to the different sets of data. 




Figure 1.

The flows and relationships between datasets 


\section{Empirical simulations}

In this section, we first introduce Taiwan's key macroeconomic indicator variables and import values by commodity/industry during 1999-2004, which data are used to calibrate the preference change. Then the three simulation results are presented and discussed.

\subsection{Taiwan's key macroeconomic indicator variables 1999-2004}

Table 2 presents the annual and cumulative growth rates of the key macroeconomic variables for Taiwan. Table 3 presents import data by commodity. Both sets of data are used to simulate changes in preferences from 1999 to 2004. As shown in Table 2, the total growth in GDP in the period 1999-2004 is $18.96 \%$, mainly contributed by the growth in real exports and real household expenditure. In 2001, the Taiwanese economy suffered from the global economic recession when real investment and real exports shrank, resulting in a negative real GDP growth. However, the economy gradually rebounded in the subsequent three years. In 2004, its economic growth rate was above that of 2000.

As shown in Table 3, the total value of imports grew from NT\$ 4,276 million in 1999 to NT\$ 6,373 million in 2004, representing a cumulative increase of $49.05 \%$. The average price of imported commodities increased by $14.88 \% .5$ ) The import value of various commodities varies widely. Overall, imports of chemical and heavy industrial products represented more than two thirds of total import value. Electronic products, machinery and minerals had the three highest import values, reflecting the fact that most of Taiwan's commodity imports are raw materials, capital goods and intermediate products. During the same period, the change of price for different imported commodities also varied. The prices of bulk materials, such as minerals, non-metallic mineral products, iron and steel increased by approximately $70 \%$, but those of electronic products, electrical equipment and appliances fell by about $20 \%$. As a small open economy, Taiwan is mostly a price-taker for most of imported commodities.

5) The 1999-2004 accumulated growth rate of real commodity imports is $34.17 \%$. It is a little lower than that of real imports of Table $2(36.26 \%$, which includes the imports of services. 
Table 2.

The growth rates of key macroeconomic variables of Taiwan, 2000-2004

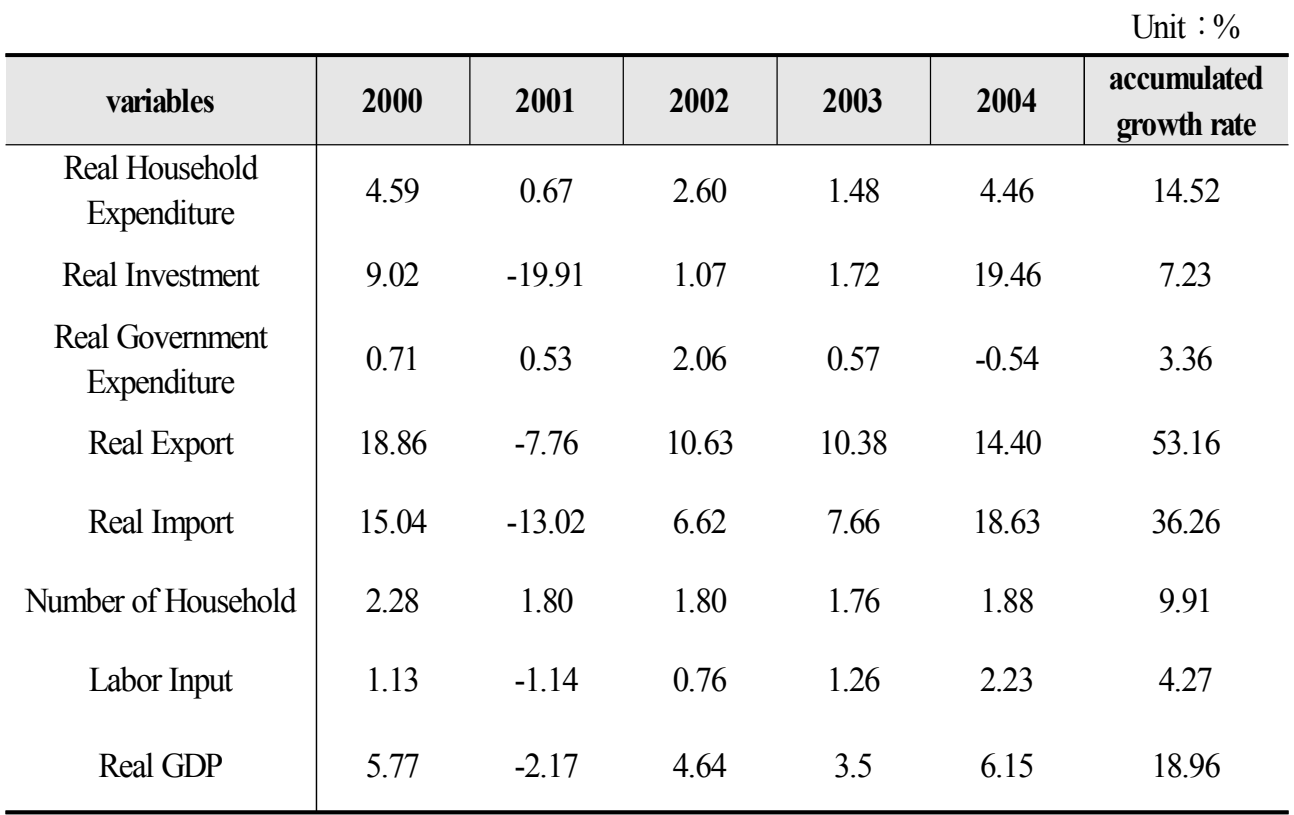

Source: Directorate-General of Budget, Accounting and Statistics, Executive Yuan, R.O.C., Macro Statistic Database. http://www.stat.gov.tw/public/data/dgbas03/bs4/nis93/np14.xls

\section{Table 3.}

Import Data by Commodity, 1999 and 2004

\begin{tabular}{|c|c|c|c|c|}
\hline Commodities & $\begin{array}{c}1999 \\
\text { import } \\
\text { value } \\
\text { (NT\$1000) } \\
(1) \\
\end{array}$ & $\begin{array}{c}2004 \\
\text { import } \\
\text { value } \\
\text { (NT\$1000) } \\
(2) \\
\end{array}$ & $\begin{array}{c}\text { \% change of } \\
\text { import value } \\
{[(2) /(1)]-1} \\
(\%)\end{array}$ & $\begin{array}{c}\text { \% change of } \\
\text { importprice } \\
(\%)\end{array}$ \\
\hline Agriculture and Animal Husbandry & 76,253 & 87,447 & 14.68 & 23.10 \\
\hline Forest Products & 8,758 & 11,640 & 32.91 & 23.10 \\
\hline Fishing & 11,561 & 10,293 & -10.97 & 23.10 \\
\hline Minerals & 246,735 & 675,812 & 173.90 & 73.90 \\
\hline Food Processing & 107,953 & 118,896 & 10.14 & 7.29 \\
\hline Beverage & 24,108 & 49,529 & 105.45 & 7.29 \\
\hline Tobacco & 19,062 & 44,941 & 135.76 & 7.29 \\
\hline Textiles & 46,560 & 32,616 & -29.95 & 6.77 \\
\hline Apparel, Clothing Accessories & 70,834 & 87,356 & 23.32 & 6.77 \\
\hline
\end{tabular}




\begin{tabular}{|c|c|c|c|c|}
\hline Commodities & $\begin{array}{c}1999 \\
\text { import } \\
\text { value } \\
\text { (NT\$1000) } \\
(1) \\
\end{array}$ & $\begin{array}{c}2004 \\
\text { import } \\
\text { value } \\
(\mathrm{NT} \$ 1000) \\
(2) \\
\end{array}$ & $\begin{array}{c}\text { \% change of } \\
\text { import value } \\
{[(2) /(1)]-1} \\
(\%)\end{array}$ & $\begin{array}{c}\text { \% change of } \\
\text { importprice } \\
(\%)\end{array}$ \\
\hline Wood and Wood Products & 40,313 & 43,607 & 08.17 & 15.99 \\
\hline Papers, Paper Products \& Printing & 75,104 & 91,303 & 21.57 & 16.16 \\
\hline Chemical Products & 221,016 & 345,707 & 56.42 & 36.73 \\
\hline Synthetic Fiber & 6,358 & 9,083 & 42.86 & 36.73 \\
\hline Plastics & 63,219 & 78,013 & 23.40 & 33.28 \\
\hline Plastic Goods & 35,882 & 100,355 & 179.68 & 33.28 \\
\hline Other Chemical Products & 165,676 & 285,667 & 72.42 & 27.39 \\
\hline Refined Petroleum Products & 76,881 & 147,924 & 92.41 & 27.39 \\
\hline Non-metallic Mineral Products & 45,232 & 78,737 & 74.07 & 73.90 \\
\hline Iron and Steel & 145,704 & 338,456 & 132.29 & 68.88 \\
\hline Other Metal & 156,371 & 241,793 & 54.63 & 43.00 \\
\hline Metal Products & 40,928 & 58,393 & 42.67 & 57.25 \\
\hline Machinery & 463,990 & 632,973 & 36.42 & -5.55 \\
\hline Household Appliances & 24,436 & 53,728 & 119.87 & -17.97 \\
\hline Electronic Products & 997,282 & $1,246,119$ & 24.95 & -32.26 \\
\hline Electrical Equip. \& Appliances & 130,560 & 449,157 & 244.02 & -27.60 \\
\hline Transport Equipment & 163,318 & 244,910 & 49.96 & 4.58 \\
\hline Other Mfg. Products & 236,473 & 38,764 & -83.61 & -2.98 \\
\hline Total & $4,275,630$ & $6,372,769$ & 49.05 & 14.88 \\
\hline
\end{tabular}

Source: Directorate-General of Budget, Accounting and Statistics, Executive Yuan, R.O.C..

\subsection{Simulation results}

\subsubsection{Results of historical simulation}

Before the simulations, the reliability of the model in accurately reflecting the operation of the Taiwanese economic system is tested to determine whether it suffices for the simulations. Data of macroeconomic variables, including various types of final demand (household consumption, physical investment, government expenditure and exports) and 
variables associated with production interactions among industries (input-output data by industry) are used to simulate accumulated real GDP growth in the period 1999-2004. The simulated growth is $18.96 \%$, which is a little lower than the government's published value of $19.51 \%$, representing a difference in average annual growth rate of only $0.56 \% .6$ ) Converting the growth rate into a value yields a simulated real GDP of NT $\$ 9,389$ billion in 1999, which is very close to the government's published value of NT\$9,346 billion. This difference is only $0.46 \%$. Both differences are statistically insignificant. These results provide evidence that the model illustrates the performance the Taiwanese economy in high accuracy and suffices for the simulations.

The change in import preference is now calibrated. Table 4 presents the relevant results. We found that the import preference increased for 21 out of the 27 commodities. The four commodities with highest import preference changes are other metal (21.6\%), electrical equipment and appliances (20.0\%), machinery (19.4\%) and electronic products (19.3\%). Of these, electrical equipment and appliances and machinery are capital goods, and electronic products are mostly intermediate goods. The former may be associated with the deepening of OEM production and the increased reliance of Taiwan's manufacturing sectors on imported machinery and equipment. The latter may be associated with increasing fragmentation of the global electronics production chain.

\section{Table 4.}

Calibrated change of import preference by commodity

\begin{tabular}{l|c|c}
\hline \multicolumn{1}{c|}{ Commodity } & $\begin{array}{c}\text { Total change of import } \\
\text { preference1 (\%) }\end{array}$ & $\begin{array}{c}\text { Average annual change of } \\
\text { import preference1 (\%) }\end{array}$ \\
\hline Agriculture and Animal Husbandry & -61.9 & -12.4 \\
Forest Products & 78.9 & 15.8 \\
Fishing & -48.3 & -9.7 \\
Minerals & -94.7 & -18.9 \\
Food Processing & -9.3 & -1.9 \\
Beverage & -62.7 & -12.5 \\
Tobacco & -95.6 & -19.1 \\
Textiles & 17.4 & 3.5 \\
Apparel, Clothing Accessories & -28.0 & -5.6 \\
Wood and Wood Products & -3.7 & -0.7 \\
Papers, Paper Products \& Printing & 12.5 & 2.5 \\
Chemical Products & -33.9 & -6.8
\end{tabular}

6) This simulation does not control for inventory changes, potentially causing discrepancies between the simulated results and published government statistics. 


\begin{tabular}{l|c|c}
\hline \multicolumn{1}{c|}{ Commodity } & $\begin{array}{c}\text { Total change of import } \\
\text { preference1 (\%) }\end{array}$ & $\begin{array}{c}\text { Average annual change of } \\
\text { import preference1 (\%) }\end{array}$ \\
\hline Synthetic Fiber & -15.7 & -3.1 \\
Plastics & -14.1 & -2.8 \\
Plastic Goods & -49.0 & -9.8 \\
Other Chemical Products & -35.8 & -7.2 \\
Refined Petroleum Products & -11.8 & -2.4 \\
Non-metallic Mineral Products & 26.8 & 5.4 \\
Iron and Steel & -45.2 & -9.0 \\
Other Metal & -108.0 & -21.6 \\
Metal Products & 15.8 & 3.2 \\
Machinery & -96.9 & -19.4 \\
Household Appliances & -79.8 & -16.0 \\
Electronic Products & -96.5 & -19.3 \\
Electrical Equip. \& Appliances & -100.1 & -20.0 \\
Transport Equipment & -50.6 & -10.1 \\
Other Mfg. Products & 596.2 & 119.2 \\
\hline
\end{tabular}

Note : Negative numbers indicate the increase of domestic buyers' preference for imports such that given relative import and domestic prices, they intend to purchase more imported goods and fewer domestic goods. Positive numbers indicate the decrease of domestic buyers' preference for imports such that given prices, they intend to purchase fewer imported goods and more domestic goods.

\subsubsection{Results of decomposition simulation}

In this simulation, the factors that affect economic growth are separated into five categories. They are, increase in total factor productivity (TFP), increase in autonomous (not price-induced) final demand, change in import prices, change in wages, and change in import preferences. The contribution of each factor to economic growth is estimated and the results are presented in Table 6.

Of these five categories, increase in total factor productivity (TFP effect) contributed the most, $19.51 \%$, to cumulative real GDP growth. The decrease in wages also promoted growth to $10.05 \%$. Increasing import prices, caused either by depreciation of the currency or by an increase in foreign prices, had a negative effect on the Taiwan's economic growth. The change in preferences toward imported goods also suppressed economic growth. Its adverse effect was not only on real GDP growth $(-9.60 \%)$ but also on real household consumption $(-8.62 \%)$ and investment $(-9.06 \%)$; however it promoted the growth of exports. 
Table 5.

Results of decomposition simulation

\begin{tabular}{c|ccc|c|c|c}
\hline Variable & $\begin{array}{c}\text { TFP } \\
\text { Effect }\end{array}$ & $\begin{array}{c}\text { Final } \\
\text { Demand } \\
\text { Effect }\end{array}$ & $\begin{array}{c}\text { Import } \\
\text { Price } \\
\text { Effect }\end{array}$ & $\begin{array}{c}\text { Import } \\
\text { Preferenc } \\
\text { e Effect }\end{array}$ & $\begin{array}{c}\text { Wage } \\
\text { Effect }\end{array}$ & $\begin{array}{c}\text { Total } \\
\text { Effect }\end{array}$ \\
\hline Real GDP & 27.01 & 4.56 & -12.50 & -9.60 & 10.05 & 19.51 \\
Real Consumption & 14.03 & 22.03 & -13.59 & -8.62 & 2.05 & 15.90 \\
Real Investment & 25.83 & -6.23 & -11.92 & -9.06 & 9.62 & 8.25 \\
Real Export & 48.82 & -12.58 & -17.57 & 11.63 & 22.57 & 52.87 \\
Government Expenditure & 0.00 & 3.36 & 0.00 & 0.00 & 0.00 & 3.36 \\
Real Import & 25.26 & 3.45 & -15.34 & 12.35 & 9.81 & 35.53 \\
\hline
\end{tabular}

\subsubsection{Results of policy simulation}

In this section, data on tariff reduction from Lin et al. (2003) are adopted (Table 6) to simulate the effects of the trade reform that Taiwan undertook to fulfill its promises upon entry to the WTO, as a policy shock. Long-run and short-run scenarios are considered to elucidate the effects of policy shock under the two conditions. The short-run scenario incorporates constant capital stock and wage stickiness while the long-run scenario allows adjustments of capital stock and wages. The simulated results are compared with those obtained without considering any change in import preferences so that bias that is caused by neglecting this change can be revealed.

Table 6.

Average tariff rates by commodity

\begin{tabular}{ccccc}
\hline Commodities & $\begin{array}{c}\text { Tariff rate before } \\
\text { WTO entry } \\
(\mathbf{1})\end{array}$ & $\begin{array}{c}\text { Target Tariff } \\
\text { (2) }\end{array}$ & $\begin{array}{c}\text { Tariff Reduction } \\
\mathbf{( 2 )}-\mathbf{( 1 )}\end{array}$ & $\begin{array}{c}\text { Power of Tariff } \\
\text { change (\%) } \\
(\mathbf{3}) *\end{array}$ \\
\hline Agricultural Products & 12.48 & 11.18 & -1.30 & -1.16 \\
Mining Products & 3.24 & 2.92 & -0.32 & -0.31 \\
$\begin{array}{c}\text { Fundamental Industry } \\
\quad \text { Products }\end{array}$ & 4.90 & 3.87 & -1.03 & -0.98 \\
$\begin{array}{c}\text { Technology Intensive } \\
\text { Products }\end{array}$ & 6.04 & 4.48 & -1.56 & -1.47 \\
$\begin{array}{c}\text { Traditional Industry } \\
\text { Products }\end{array}$ & 9.97 & 8.45 & -1.52 & -1.38 \\
\hline
\end{tabular}

Source: Lin et al. (2003)

* Power of Tariff change $=\left(\frac{1+\text { Target Tariff rate }}{1+\text { Tariff rate befor WTO entry }}-1\right) * 100$ 
To estimate the effects of tariff reduction, the reverse method is used and economic performance without such a policy is simulated. The differences between actual performance (with the policy implemented) and simulated performance are deemed to be explained as effects of the policy. As indicated in Table 7, the estimated effects of the policy on the growth of real GDP, real investment and real consumption, both in the short-run and the long-run, that are simulated while taking into account changes in import preferences are much smaller than those simulated without accounting for those changes. The short-run real GDP growth was only $0.01 \%$ with preference changes, but $0.18 \%$ without them. The long-run real GDP growth was only $0.02 \%$ with preference changes, compared with $0.21 \%$ without them. The effects of the policy on real import growth in the short-run increased from $0.55 \%$ without preference changes to $2.36 \%$ with them and, in the long-run, from $0.68 \%$ to $2.53 \%$. The policy effects on real exports with preference changes are also larger than those without them. The simulated effects of the policy shock on real export growth are $2.43 \%$ (in the short-run) and $2.61 \%$ (in the long-run) with import preference changes, which are much larger than those, $0.22 \%$ (in the short-run) and $0.29 \%$ (in the long-run), without them. These larger export growths did not accelerate Taiwan's GDP growth largely because of the decrease of the domestic content of the exports. The increasing dependence on imported components and drop in domestic value-added weakened the growth in domestic investment and slightly reduced domestic consumption.

\section{Table 7.}

Results of policy simulation

\begin{tabular}{c|c|c|c|c}
\hline \multirow{2}{*}{} & \multicolumn{2}{|c}{ Short-Run } & \multicolumn{2}{c}{ Long-Run } \\
\cline { 2 - 5 } & $\begin{array}{c}\text { Without Import } \\
\text { Preference } \\
\text { Changes }\end{array}$ & $\begin{array}{c}\text { With Import } \\
\text { Preference } \\
\text { Changes }\end{array}$ & $\begin{array}{c}\text { Without Import } \\
\text { Preference } \\
\text { Changes }\end{array}$ & $\begin{array}{c}\text { With Import } \\
\text { Preference } \\
\text { Changes }\end{array}$ \\
\hline Real GDP & 0.18 & 0.01 & 0.21 & 0.02 \\
Real Import Volume & 0.55 & 2.36 & 0.68 & 2.53 \\
Real Investment & 0.18 & 0.01 & 0.21 & 0.02 \\
Real Consumption & 0.38 & -0.11 & 0.43 & -0.12 \\
Real Export & 0.22 & 2.43 & 0.29 & 2.61 \\
\hline
\end{tabular}




\section{Conclusion}

Taiwan is a small open economy highly involved in the global production chain and deeply influenced by globalization. During the recent trend of globalization, Taiwan seemingly did not increase its comparative advantages in manufacturing by increasing the value-added associated with either its total production or exports. On the contrary, its dependence on imported products for manufacturing production and consumption has steadily grown. These findings reveal that Taiwan may have undergone a structural change in import demand. The literature states that the increase in import demand that is induced by non-price factors may have been caused by the development in global production outsourcing, an increase in product variety, and the persistence of various trade barriers. Most of CGE models do not consider the effects of these factors on import demand and so may result in biases in trade policy simulations. To solve this problem, the effects on import demand of all of these factors are incorporated into a CGE model and named "preference changes". The scale of the preference change is calibrated using data for Taiwan from 1999-2004. The effects of this preference change are simulated. Empirical results demonstrate that preferences for imports increased with respect to 21 out of 27 manufactured products, meaning that given constant relative import/domestic prices, people tended to buy more imported products. Of the 21 products, other metal (mainly raw material) exhibited the largest favorable change in preference for import, followed by electrical equipment and appliances (mainly intermediate goods), and then machinery (capital goods). These results are consistent with the development of Taiwan's OEM production pattern during the period.

The change in Taiwan's import preferences mitigated the positive economic effects of the tariff reduction policy on economic growth. Tariff reduction during 2000-2004 stimulated only $0.01 \%$ of real GDP growth in the short-run and $0.02 \%$ in the long-run, much lower than the respective simulated results of $0.18 \%$ and $0.21 \%$, without considering changes in preference. Neglect of preference changes causes the effects of trade liberalization policies on economic growth to be overestimated and their effects on imports and exports to be underestimated.

In this study we develop a computable method to empirically measure the scale the preference change and the effects it may cause. Future research may follow the line to further decompose the effects into different origins so that the impacts of each element contributing to global market environmental changes can be better understood. 


\section{Acknowledgements}

The authors would like to thank the National Science Council of the Republic of China, Taiwan, for financially supporting this research under Contract No. NSC 99-2410-H-305-017. 


\section{References}

Alston, J.M., Carter, C.A., Green, R. and Pick, D. (1990) "Whither Armington Trade Models?" American Journal of Agricultural Economics, Vol. 72, No. 2, pp. 455-467.

Armington, P.S. (1969) "The Geographic Pattern of Trade and the Effects of Price Changes.'IMF Staff Papers, 16, pp. 176-199.

Armington, P.S. (1970) "Adjustment of Trade Balances: Some Experiments with a Model of Trade among Many Countries."IMF Staff Papers, 17, pp. 477-523.

Ballard, C.L., Fullerton, D., Shoven, J.B. and Whalley J. (1985) "A General Equilibrium Model for Tax Policy Evaluation." Chicago : University of Chicago Press for the National Bureau of Economic Research.

Brooks, N., Buzby, J. C., and RegmiA. (2009), "Globalization and Evolving Preferences Drive U.S. Food-Import Growth,"Journal of Food Distribution Research, Vol.40, No.1, pp.39-46.

Buetre, B.L. and Ahmadi-Esfahani, F.Z. (2000) "Updating an input-output table for use in policy analysis."The Australian Journal of Agricultural and Resource Economics, Vol. 44, No. 4, pp. 573-603.

Dervis, K., and de Melo, J. and Robinson, S. (1982) General Equilibrium Models for Development Policy, Cambridge University Press, New York.

Dixon, P.B., Parmenter, B.R., Sutton, J.M. and Vincent, D.P. (1982) ORANI: A Multisectoral Model of the Australian Economy, Amsterdam: North-Holland.

Dixon, P.B., Parmenter, B.R., Powell, A.A. and Wilcoxen, P.J. (1992) Notes and Problems in Applied General Equilibrium Economics, Amsterdam: North-Holland.

Dixon, P.B. and Rimmer, M.T. (2000) Forecasting, Policy, History and Decomposition: The Monash Model of the Australian Economy. Centre of Policy Studies, Monash University, Australia. 
Feenstra, R.C. (1994a) "New Product Varieties and the Measurement of International Prices," American Economic Review, Vol.84, No. 1,pp. 157-177.

Feenstra R.C. and Markusen, J. (1994b), "Accounting for Growth with New Inputs," International Economic Review, Vol.35, No. 2, 429-447.

Feenstra R.C. and Taylor, A.M. (2008), International Economics, Worth Publishers, New York.

Frazao, B., Meade, B., and Regmi A. (2008), "Converging Patterns in Global Food Consumption and Food Delivery Systems." Amber Waves, Vol. 6, No.1, pp. 22-29.

Fullerton, D.A., King, T., Shoven, J.B. and Whalley, J. (1981)“Corporate Tax Integration in the United States : A General Equilibrium Approach.” American Economic Review, Vol. 71, No. 4, pp. 677-691.

Fullerton, D.A. and Henderson, Y.K. (1989) "A Disaggregate Equilibrium Model of the Tax Distortions among Assets, Sectors and Industies." International Economic Review, Vol. 30, No. 2, pp. 391-413.

Gereff, G. and Fernandez-Stark, K. (2011), Global Value Chain Analysis: APrimer, Center on Globalization, Governance \& Competitiveness, Duke University, North Carolina, USA.

Horridge, M. (2004) ORANI-G 2003: A Generic Single-Country Computable General Equilibrium Model. Center for Policy Studies, Monash University, Melbourne, Australia.

Koopman, R., Wang, Z. and Wei, S.J. (2014), "Tracing value-added and double counting in gross exports."American Economic Review, Vol.104, No.2, pp. 459-494.

Küster, R., Ellersdorfer, I.R. and Fahl, U. (2007) "A CGE-Analysis of Energy Policies Considering Labor Market Imperfections and Technology Specifications", SSRN Working Paper Series. 
Lin, K.-J., Hsu, S.-H.and Li, P.-C. (2003) "An Applied General Equilibrium Analysis of WTO Tariff Reduction on Taiwan's Economy with Scale Economies and Imperfect Competition"Academia Economic Papers, Vol.31, No.4, pp. 637-674. (in Chinese)

Robertson, R. (2004) "Relative Prices and Wage Inequality: Evidence from Mexico," Journal of International Economics, Vol. 64, pp. 387-409.

Wang, Z., Wei, S-J, and Zhu, K. (2013), "Quantifying international production sharing at the bilateral and sector levels.”NBER Working Paper 19677.

Yang, T.-H.and Su, H.-P. (2002) "the Welfare Costs and Tax Structural Effects of Green Tax Reform,"Agriculture and Economics, 29, pp.29-54. (in Chinese) 


\section{Appendix: The Main Structure and Equations of the CGE Model}

\section{Substitution between Domestic and Imported Products ${ }^{7}$ )}

(a) $X_{(i s)}^{(u)}=X_{(i .)}^{(u)} \Psi_{(i s)}^{(u)}\left(P_{(i 1)}^{(u)} ; P_{(i 2)}^{(u)}\right)$

(b) $X_{(i s)}^{(u)}=X_{(i .)}^{(u)}-\sigma_{i}^{(u)}\left[p_{(i s)}^{(u)}-\sum_{t=1,2}\{V(i, t(u)) / V(i, .,(u))\} p_{(i t)}^{(u)}\right]$,

$i=1, \ldots, g ; s=1,2 ;(u)=(3),(4)$ and $(k j) ; k=1,2 j=1, \ldots, h$

$X_{(i s)}^{(u)}$ is the demand of commodity and factor by user $(u), X_{(i .)}^{(u)}$ is the demand of composite commodities and composite factor by user $(u) . \Psi_{(i s)}^{(u)}$ is a function based on the assumptions of cost minimization, revenue maximization of classical school. The combination of input demands is CES function. By contrast, the combination of output supply is CET function. $P_{(i s)}^{(u)}$ is purchasers' price for commodity and factor by user $(u)$.

\section{Substitution between Labor and Capital}

(a) $X_{(g+1, s)}^{(1 j)} / A_{(g+1, s)}^{(1 j)}=X_{(g+1 .)}^{(1 j)} \Psi_{(g+1, s)}^{(1 j)}\left(P_{(g+1,1)}^{(1 j)} / A_{(g+1,1)}^{(1 j)} ; P_{(g+1,2)}^{(1 j)} / A_{(g+1,2)}^{(1 j)}\right)$

(b) $x_{(g+1, s)}^{(1 j)}-a_{(g+1, s)}^{(1 j)}=x_{(g+1 .)}^{(1 j)} \sigma_{(g+1)}^{(1 j)}\left(p_{(g+1, s)}^{(1 j)}-a_{(g+1, s)}^{(1 j)}\right)$

$$
\begin{aligned}
& -\sum_{t=1,2}\{V(g+1, t,(1 j)) / V(g+1, .,(1 j))\}\left(p_{(g+1, t)}^{(1 j)}-a_{(g+1, t)}^{(1 j)}\right), \\
& j=1, \ldots, h ; s=1,2
\end{aligned}
$$

$X_{(g+1, s)}^{(1 j)}$ is demand of capital in industry $j$, and $A_{(g+1, s)}^{(1 j)}$ is total factor productivity in industry $j$.

7) Equation (a): indicates level form, Equation (b): indicates percentage form 


\section{Household Demands for Composite Commodities}

(a) $P_{(i .)}^{(3)} X_{(i .)}^{(3)}=\gamma_{i} P_{(i .)}^{(3)} Q+\beta_{i}\left(C-\sum_{j \in G} \gamma_{j} P_{(i .)}^{(3)} Q\right)$

(b) $V(i, .,(3))\left(p_{(i .)}^{(3)}+x_{(i .)}^{(3)}\right)=\gamma_{i} P_{(i .)}^{(3)} Q\left(p_{(i .)}^{(3)}+q\right)$

$$
+\beta_{i}\left(C_{c}-\sum_{j \in G} \gamma_{j} P_{(i .)}^{(3)} Q\left(p_{(i .)}^{(3)}+q\right)\right), i=1, \ldots, g
$$

$P_{(i .)}^{(3)}$ is purchasers' price for commodities $i . X_{(i .)}^{(3)}$ is household demand of commodity $i . \gamma_{i}$ is a parameter which belong to basic demand in linear expenditure system( $L E S)$. $\beta_{i}$ is a parameter that is marginal share of budget in linear expenditure system(LES). $C$ is total consumption expenditure. $Q$ is the number of household.

\section{Prices of Commodities to Households}
(a) $P_{(i .)}^{(3)} X_{(i .)}^{(3)}=\sum_{t=1,2} P_{(i t)}^{(3)} X_{(i t)}^{(3)}$
(b) $P_{(i .)}^{(3)}=\sum_{t=1,2}\{V(i, t,(3)) / V(i, .,(3))\} P_{(i t)}^{(3)} ; i=1, \ldots, g$

\section{Intermediate and Investment Demands for Composites, Commodities and Primary Factors}

(a) $X_{(i .)}^{(u)}=Z^{(u)} A_{i}^{(u)}$

(b) $x_{(i .)}^{(u)}=z^{(u)}$

$$
\begin{aligned}
& (u)=(3),(4) \text { and }(k j) ; k=1,2 j=1, \ldots, h \\
& \text { if }(u)=(1 j) \text { then } i=1, \ldots, g+1 ; \text { if }(u)=(2 j) \text { then } i=1, \ldots, g
\end{aligned}
$$


$Z^{(u)}$ is real output $(k=1)$ and real investment $(k=2)$ in industry $j . A_{i}^{(u)}$ is parameter of technology or preference for commodity $i$ by user $u$.

\section{Foreign Demands (Exports) for Domestic Goods}

(a) $P_{(i 1)}^{(4)} E=F_{(i 1)}^{(4)}\left(X_{(i 1)}^{(4)}\right)^{-1 / \eta_{i}}$

(b) $P_{(i 1)}^{(4)} e=f_{(i 1)}^{(4)}-\left(1-\eta_{i}\right) x_{(i 1)}^{(4)}, i=1, \ldots, g$

$F_{(i 1)}^{(4)}$ is the shift of factor demand in foreign. $\eta_{i}$ is foreign demand elasticity of domestic commodity. $E$ is nominal exchange rate (foreign currency/ domestic currency).

\section{Margins Demands for Domestic Goods}

(a) $X_{(\gamma 1)}^{(i s)(u)} X_{(i s)}^{(u)} A_{(\gamma 1)}^{(i s)(u)}, r, i=1, \ldots, g$

$$
(u)=(3),(4) \text { and }(k j), k=1,2, j=1, \ldots, h
$$

(b) $X_{(\gamma 1)}^{(i s)(u)} x_{(i s)}^{(u)} \quad$ if $(u)=(4)$, then $s=1$

$$
\text { if }(u) \neq(4) \text {, then } s=1,2
$$

$X_{(\gamma 1)}^{(i s)(u)}$ is demand of transportation service $A_{(\gamma 1)}^{(i s)(u)}$ is a parameter, a share for the use of margin which purchasing per unit of good.

\section{Composition of Output by Industries}

(a) $X_{(i 1)}^{(0 j)} Z^{(1 j)} \Psi_{(i 1)}^{(0 j)}\left(P_{(11)}^{(0)}, P_{(12)}^{(0)}, \ldots, P_{(g 1)}^{(0)}\right)$ 
(b) $x_{(i 1)}^{(0 j)} z^{(1 j)}+\sigma^{(0 j)}\left[P_{(i 1)}^{(0)}-\sum_{t \in G}\{Y(t, j) / Y(., j)\} p_{(t 1)}^{(0)}\right]$,

$j=1, \ldots, h, i=1, \ldots, g$

$X_{(i 1)}^{(0 j)}$ is real output of commodity $i$ in industry $j . Z^{(1 j)}$ is real output $(k=1)$ in industry $j$.

\section{Demand Equals Supply for Domestic Commodities}

(a) $\sum_{j \in H} X_{(t 1)}^{(0 j)}=\sum_{(u) \in U} X_{(t 1)}^{(u)}+\sum_{i \in G s} \sum_{s=1,2(u) \in U^{*}} X_{(t 1)}^{(i s)(u)}+\sum_{i \in G} X_{(t 1)}^{(i 1)(4)}$

(b) $\sum_{j \in H} Y(t, j) x_{(t 1)}^{(0 j)}=\sum_{(u) \in U} B(t, 1,(u)) x_{(t 1)}^{(u)}+\sum_{i \in G s} \sum_{s, 2} \sum_{(u) \in U^{*}} M(t, i, s,(u)) x_{(t 1)}^{(i s)(u)}$

$+\sum_{i \in G} M(t, i, 1,(4)) x_{(t 1)}^{(i s)(4)}, t=1, \ldots, g$

\section{Industry Revenue Equals Industry Costs}

(a) $\sum_{t \in G} X_{(t 1)}^{(0 j)} P_{(t 1)}^{(0)}=\sum_{t \in G^{*} s} \sum_{s=1,2} X_{(t s)}^{(1 j)} P_{(t s)}^{(1 j)}$

(b) $\sum_{t \in G} Y(t, j) P_{(t 1)}^{(0)}=\sum_{t \in G^{*} s=1,2} \sum_{l} V(t, s,(1 j)) p_{(t s)}^{(1 j)}, j=1, \ldots, h$

\section{Basic Price of Imported Commodities}

(a) $P_{(i 2)}^{(0)}=\left(P_{(i 2)}^{(0)} / E\right) T_{(i 2)}^{(0)}$

(b) $P_{(i 2)}^{(0)}=P_{(i 2)}^{(0)}-e+t_{(i 2)}^{(0)}, i=1, \ldots, g$

$P_{(i 2)}^{(0)}$ is basic price of imported commodity $(s=2) . T_{(i 2)}^{(0)}$ is the rate of make-up tariff from commodity $i$ (Rate of make-up tarif $f=1+$ imported tariff rate). 


\section{Purchasers' Price Related to Basic Prices and Taxes}

(a) $P_{(i s)}^{(u)}=P_{(i s)}^{(0)} T(i, s,(u))+\sum_{\gamma \in G} P_{(\gamma 1)}^{(0)} A_{(\gamma 1)}^{(i s)(u)}$

(b) $V(i, s,(u)) P_{(i s)}^{(u)}=(B(i, s,(u))+T(i, s,(u)))\left(P_{(i s)}^{(0)}+t(i, s,(u))\right)$

$+\sum_{\gamma \in G} M(\gamma, i, s,(u)) P_{(\gamma 1)}^{(0)}$

$i=1, \ldots, g ; g ;(u)=(3),(4),(k j)$,

$k=1,2, j=1, \ldots, h$

if $(u)=(4)$, then $s=1 ;$ if $(u) \neq(4)$, then $s=1,2$

$P_{(i s)}^{(u)}$ is price of commodity from source by user. $P_{(i s)}^{(0)}$ is the basic domestic $(s=1)$ and imported $(s=2)$. price of commodity. $T(i, s,(u))$ is the tariff rate of commodity is paid by user.

\section{Investment Behavior}

(a) $X_{(g+1,2)}^{(1 j)}(1) / X_{(g+1,2)}^{(1 j)}=F_{k} F_{k}^{(j)}\left[P_{(g+1,2)}^{(1 j)} / P_{k}^{(1 j)}-\delta_{j}\right]^{\alpha j}$

(b) $x_{(g+1,2)}^{(i j)}(1)-x_{(g+1,2)}^{(1 j)}=f_{k}+f_{k}^{(j)}$

$\left.+\alpha_{j}\left[P_{(g+1,2)}^{(1 j)}+\left(1-\delta_{j}\right) P_{k}^{(1 j)}\right)\right]\left(P_{(g+1,2)}^{(1 j)}-p_{k}^{(1 j)}\right)$

$j=1, \ldots, h$

$X_{(g+1,2)}^{(1 j)}(1)$ is capital stock in industry $j$ in the end of period. $X_{(g+1, s)}^{(1 j)}$ is capital stock in industry $j$ in the beginning of period. $F_{k}$ is the overall shifter in capital. $F_{k}^{(j)}$ is the shifter of capital in industry $j . \delta_{j}$ is the depreciation rate of capital in industry $j . \alpha_{j}$ is the sensitivity of rate of capital return to capital growth. 


\section{Capital Accumulation}

(a) $X_{(g+1,2)}^{(1 j)}(1)=X_{(g+1,2)}^{(1 j)}\left(1-\delta_{j}\right)+Z^{(2 j)}$

(b) $X_{(g+1,2)}^{(i j)}(1) x_{(g+1,2)}^{(1 j)}(1)=X_{(g+1,2)}^{(1 j)}\left(1-\delta_{j}\right) x_{(g+1,2)}^{(1 j)}+Z^{(2 j)} z^{(2 j)}$,

$j=1, \ldots, h$

$X_{(g+1,2)}^{(1 j)}(1)$ is capital stock in industry $j$ in the end of period. $X_{(g+1, s)}^{(1 j)}$ is capital stock in industry $j$ in the beginning of period. $\delta_{j}$ is the depreciation rate of capital in industry $j . Z^{(2 j)}$ is the real expenditure of investment $(k=2)$ in industry $j$.

\section{Costs of Constructing Units of Capital for Industries}

(a) $P_{k}^{(1 j)} Z^{(2 j)}=\sum_{i \in G s} \sum_{i, 2} P_{(i s)}^{(2 j)} X_{(i s)}^{(2 j)}$

(b) $V(., .,(2 j)) p_{k}^{(1 j)}=\sum_{i \in G s} \sum_{s=1,2} V(i, s,(2 j)) p_{(i s)}^{(2 j)}, j=1, \ldots, h$

$P_{k}^{(1 j)}$ is the cost of constructing units of capital for industries.

\section{Wage Determination}

(a) $P_{(g+1,1)}^{(1 j)}=(C P I) F_{(g+1,1)}^{(1 j)} F_{(g+1,1)}$

(b) $p_{(g+1,1)}^{(1 j)}=c p i+f_{(g+1,1)}^{(1 j)}+f_{(g+1,1)} ; j=1, \ldots, h$

$P_{(g+1,1)}^{(1 j)}$ is the cost of labor in industry $j$ in beginning of period. $C P I$ is the Consumer Price Index. $F_{(g+1,2)}^{(1 j)}$ is the shifting factor of wage in the industry. $F_{(g+1,1)}$ is the neutral shifting factor in wage. 


\section{Consumer Price Index}

(a) $C P I=\prod_{i \in G s} \prod_{=1,2}\left(P_{(i s)}^{(3)}\right)^{\bar{V}(i, s, 3) / \bar{V}(. .,(3))}$
(b) $c p i=\sum_{i \in G s} \sum_{s=1,2}(\bar{V}(i, s, 3) / \bar{V}(., .,(3))) p_{(i s)}^{(3)}$

$P_{(i s)}^{(3)}$ is the price of commodity purchased by household. $V(i, s, 3)$ is the number of household in the transaction. $C P I$ is a aggregation of different prices of commodities in household sector.

\section{Tax Rates on Sales to Households}

(a) $T(i, s,(3))=T_{b}(i, .,(3)) F_{t}(3)$

(b) $t(i, s,(3))=t_{b}(i, .,(3))+f_{t}(3), i=1, \ldots, g, i=1, \ldots, h$

$T(i, s,(3))$ is the tax on sales is to household. $T_{b}(i, .,(3))$ is the tax rate of different commodities to household. $F_{t}(3)$ is the shifter of indirect tax.

\section{Ratio of Real Investment to Real Consumption}

(a) $I_{R} / C_{R}=F I C$

(b) $i_{R} / c_{R}=f i c$

$I_{R}$ is the Real Aggregate Expenditure of Investment. $C_{R}$ is the Real Aggregate Expenditure of Consumption. FIC is the proportion of real investment to real expenditure of consumption. 


\section{Balance of Payment in Industries}

(a) VGOS $=V 1 C A P \_I+V 1 O C T \_I+V R O W G O S+V G O V G O S$

$V G O S A V=V G O S-\sum_{h} V G O S H O U_{(h)}-V G O S G O V-V G O S T A X-V G O S R O W$

VGOSTAX $=$ FGOSTAX $\operatorname{VGOS}$

(b) $V G O S \times w g o s=V 1 C A P \_I \times w 1 c a p \_i+V 1 L N D \_I \times w 1 \ln d \_i$

+ VROWGOS $\times$ wrowgos + VGOVGOS $\times$ wgovgos

$$
\begin{aligned}
& \text { VGOSSA V } \times \text { wossav }=V G O S \times \text { wgos }-\sum_{h} V_{G O S H O U_{(h)}} \times \text { wgoshou }_{(h)} \\
& \text { - VGOSGOV } \times \text { wgosgov - VGOSTAX } \times \text { wgostax } \\
& \text { - VGOSROW } \times \text { wgosrow }
\end{aligned}
$$

$w$ gostax $=$ fgostax + wgos

Industrial income:

Industry income $(V G O S)$ is defined as the sum of industrial capital and land investment income $\left(V 1 C A P_{-} I_{\text {and }} V 1 L N D_{-}\right)$, transfer received from government (VGOVGOS) and from foreign (VROWGOS).

Industry expenditure and saving:

Industry expenditures includes dividends for investors (VGOSHOU), all transfer payment to government and foreign ( $V G O S G O V$ and $V G O S R O W$ ), industry direct tax (VGOSTAX) and other expenses. The subtraction between income and expenditure are savings for the industry (VGOSSAV).

Industry direct tax:

Industry direct tax (VGOSTAX) is defined as the industry direct tax rate (FGOSTAX) multiplied by industrial income (VGOS). 


\section{Balance of Payment in Households}

(a) $\operatorname{VHOUSINC}_{(h)}=\operatorname{VGOSHOU}_{(h)}+V 1$ LABINC__ $_{(h)}+\sum_{\text {from }} \operatorname{VHOUHOU}_{(h, \text { from })}$

$$
\begin{aligned}
& +\operatorname{VGOVHOU}_{(h)}+\operatorname{VROWHOU}_{(h)} \\
\operatorname{VHOUSAV}_{(h)} & =\operatorname{VHOUSINC}_{(h)}-\operatorname{VBTOT}_{(h)}-\sum_{t o} \operatorname{VHOUHOU}_{(t o, h)}-\operatorname{VHOUGOV}_{(h)} \\
- & \operatorname{VHOUROW}_{(h)} \\
\operatorname{VHOUGOV}_{(h)} & =\operatorname{INCTAXRATE}_{(h)} \cdot \operatorname{VHOUSINC}_{(h)}
\end{aligned}
$$

(b) $\operatorname{VHOUSINC}_{(h)} \times$ whousinc $_{(h)}=\operatorname{VGOSHOU}_{(h)} \times$ wgoshou $_{(h)}$

$$
\begin{aligned}
& +{\operatorname{VILABINC} \_O_{(h)} \times \text { wllabinc_o }}_{(h)} \\
& +\sum_{\text {from }} \operatorname{VHOUHOU}_{(h, \text { from })} \times \text { whouhou }_{(h, f r o m} \\
& +\operatorname{VGOVHOU}_{(h)} \times \operatorname{wgovhou}_{(h)} \\
& +\operatorname{VROWHOU}_{(h)} \times \text { wrowhou }_{(h)}
\end{aligned}
$$

$\operatorname{VHOUSAV}_{(h)} \times$ whousav $_{(h)}=\operatorname{VHOUSINC}_{(h)} \times$ whousinc $_{(h)}$

$$
\begin{aligned}
& -\operatorname{V3TOT}(h) \times w 3 \operatorname{tot}(h) \\
& -\sum_{t o} \operatorname{VHOUHOU} \\
& (t o, h) \\
& \times \text { whouhou }_{(t o, h)}
\end{aligned}
$$$$
-\operatorname{VHOUGOV}_{(h)} \times \text { whougov }_{(h)}
$$$$
-\operatorname{VHOUROW}_{(h)} \times \text { whourow }_{(h)}
$$

whougov $_{(\mathrm{h})}=$ whousinc $_{(\mathrm{h})}+\mathrm{f}_{-}$inctaxrate $_{(\mathrm{h})}+\mathrm{f}_{-}$inctaxrate_h

Household income:

Household income (VHOUSINC) is the sum of transfer received from industry, government, and foreign (VGOSHOU, VGOVHOU and VROWHOU), labor income (VILABINC_O), transfer inter-household (VHOUHOU) etc.

Household expenditure and saving:

Household expenditure includes household consumption expenditure (V3TOT, the total for the domestic and import goods with commodity tax and tariffs), transfer inter-household $(\mathrm{VHOUHOU})$, direct tax ( $\mathrm{VHOUGOV}$ ) and transfer payment (VHOUROW). Household income minus household expenditure is equal to household savings (VHOUSAV). 
Household direct tax:

Household direct tax (VHOUGOV) is set by household direct tax rate (INCTAXRATE) $\mathrm{x}$ household income (VHOUSINC).

\section{Balance of Payment in Government}

(a) VINCGOV $=$ VOTAX_CSI + VGOSGOV $+V G O S T A X+\sum_{h} V H O U G O V_{(h)}$

$$
+ \text { VROWGOV +VIOCT_I }
$$

VGOVEXP $=$ VGOVCUR + VGOVCAP

$V G O V C U R=V 5 T O T+V G O V G O S+\sum_{h} V G O V H O U_{(h)}+V G O V R O W$

$\operatorname{VGOVCAP}=\sum_{i} \operatorname{GOVSHRINV}_{(i)} \cdot \operatorname{V2TOT}_{(i)}$

(b) VINCGOV $\times$ wincgov $=$ VOTAX_CSI $\times$ w0tax_csi + VGOSGOV $\times$ vgosgov

$$
\begin{aligned}
& + \text { VGOSTAX } \times \text { wgostax }+\sum_{h} \text { VHOUGOV } \\
& (h) \times \text { whougov }_{(h)} \\
& + \text { VROWGOV } \times \text { wrowgov }+ \text { VIOCT_I } \times \text { wloct_i }
\end{aligned}
$$

VGOVEXP $\times$ wgovexp $=$ VGOVCUR $\times$ wgovcur $+V G O V C A P \times 2$ govcap

VGOVCUR $\times$ wgovcur $=$ V5TOT $\times$ w5tot $+V G O V G O S \times$ wgovgos

$$
\begin{aligned}
&+\sum_{h} \operatorname{VGOVHOU}_{(h)} \times \text { wgovhou }_{(h)}+\operatorname{VGOVROW} \times \text { wgovrow } \\
& \text { VGOVCAP } \times \text { wgovcap }=\sum_{i} \operatorname{GOVSHRINV}_{(i)} \cdot \operatorname{V}_{2} \operatorname{TOT}_{(i)} \times w_{2} \text { tot }_{(i)}
\end{aligned}
$$

Government income:

Government income is the sum of indirect tax revenue (VOTAX_CSI), transfer received from industry and foreign ( $V G O S G O V$ and $R O W G O V$ ), industrial direct tax (VGOSGOV), household direct tax (VHOUGOV) and other cost of industry (VIOCT_I).

Government expenditure:

Government expenditure are divided into recurrent expenditure (VGOVCUR) and fixed government investment $(V G O V C A P)$. 
Government recurrent expenditure:

Government expenditure includes government consumption (V5TOT) and all transfer payments (VGOVGOS, VGOVHOU and VGOVROW)

Government investment:

Government investment is a fixed proportion (GOVSHRINV) of all investments (V2TOT). 